\title{
Karkas Ayam Broiler Yang Diberi Umbi Amorphophallus companulatus
}

\section{Carcass of Broiler Chickens Fed with Amorphophallus companulatus}

\author{
Theresia Nur Indah Koni' ${ }^{1 *}$, Tri Anggarini Yuniwaty Foenay ${ }^{2)}$, Hieronymus Yohanes \\ Chrysostomus ${ }^{3)}$ \\ ${ }^{1)}$ Program Studi Teknologi Pakan Ternak, Jurusan Peternakan, Politeknik Pertanian Negeri Kupang \\ ${ }^{2)}$ Program Studi Produksi Ternak, Jurusan Peternakan, Politeknik Pertanian Negeri Kupang \\ J1. Prof. Dr. Herman Yohanis, Lasiana, Kupang 85011, NTT, Indonesia \\ ${ }^{3)}$ Program Studi Budidaya Ternak, Jurusan Peternakan, Fakultas Peternakan, Universitas Papua \\ Jl. Gunung Salju, Amban Manokwari 98314, Papua Barat, Indonesia
}

\section{Article history \\ Received: Aug 10, 2020; \\ Accepted: Mar 06, 2021 \\ * Corresponding author: \\ E-mail: \\ indahkoni@gmail.com \\ DOI: \\ 10.46549/jipvet.v11i1.135

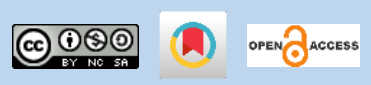

\begin{abstract}
Amorphophallus companulatus $(A C)$ is a plant from the Araceae family that contains high metabolizable energy and an alternative feedstuff for livestock. This study aimed to investigate the effect of feeding diet containing $A C$ on slaughter weight, carcass weight, and abdominal fat of broiler chickens. The feeding trial lasted for 35 days. For the sample, 112 broiler chicks, all a day old were used. The research had 4 treatment groups and 4 replications with 7 birds per replication. The four treatments were $\mathrm{P} 0$ (Control ration without $A C$ ); $\mathrm{P} 1$ (rations containing $5 \%$ of $A C$ ); $\mathrm{P} 2$ (rations containing $10 \%$ of $A C$ ); $\mathrm{P} 3$ (rations containing $15 \% \mathrm{AC}$ ). Slaughter weight, carcass weight, and abdominal fat weight data were analyzed by variance analysis and followed by Duncan's multiple range test with a confidence level of 0.05 . The addition of $A C$ tubers affected the slaughter weight, carcass weight, and abdominal fat weight of broiler chickens. The slaughter and carcass weight in chickens fed with the control ration was significantly $(\mathrm{P}<0.05)$ higher than the chicken fed with rations containing $A C$. The abdominal fat weight was significantly $(\mathrm{P}<0.05)$ higher in chickens fed with control rations compared to those fed with $A C$ rations. In conclusion, $A C$ tuber meal in the ration can reduce the slaughter weight, carcass weight, and abdominal fat weight of broiler chickens.
\end{abstract}

Keywords: Abdominal fat; Amorphophallus companulatus; Broiler; Carcass weight; Final body weight.

\section{Abstrak}

Amorphophallus companulatus (AC) merupakan Araceae yang mengandung energi metabolisme yang tinggi dan sebagai bahan pakan alternatif bagi ternak. Penelitian ini bertujuan untuk mengkaji pengaruh penggunaan $A C$ dalam ransum terhadap bobot potong, berat karkas, dan lemak abdominal ayam broiler. Penelitian ini dilakukan selama 35 hari. Seratus dua belas ekor ayam broiler umur sehari digunakan dalam penelitian. Ada 4 kelompok perlakuan dengan 4 ulangan masing-masing 7 ekor ayam per ulangan. Keempat perlakuan tersebut adalah P0 (Ransum kontrol tanpa $A C$ ); P1(ransum yang mengandung 5\% AC); P2 (ransum yang mengandung 10\% AC); P3 (ransum yang mengandung 15\% AC). Data berat potong, berat karkas dan berat lemak abdominal dianalisis dengan analisis varians dan dilanjutkan dengan uji jarak berganda Duncan pada tingkat kepercayaan 0,05. Pemberian umbi $A C$ berpengaruh terhadap berat badan akhir, berat karkas dan berat lemak abdominal ayam broiler. Berat badan akhir, berat karkas pada ayam yang diberi ransum kontrol secara nyata $(\mathrm{P}<0,05)$ lebih tinggi daripada ayam yang diberi ransum mengandung $A C$. Bobot lemak abdominal secara nyata $(\mathrm{P}<0,05)$ lebih tinggi pada ayam yang diberi ransum kontrol dibandingkan yang diberi 
ransum $A C$. Kesimpulannya, tepung umbi $A C$ dalam ransum dapat mengurangi berat badan akhir, berat karkas dan lemak abdominal ayam broiler.

Kata kunci: Lemak abdominal; Amorphophallus companulatus; Broiler; Berat karkas; Berat badan akhir.

\section{Pendahuluan}

Sumber protein hewani bagi masyarakat salah satunya berasal dari daging ayam broiler. Kebutuhan masyarakat akan daging broiler akan terpenuhi jika didukung dengan peningkatan produksi. Produktifitas ternak dipengaruhi oleh berbagai faktor, salah satu faktor yang berperan penting adalah kualitas dan kuantitas pakan yang diberikan. Pada peternakan unggas $70 \%$ dari total biaya produksi diperuntukan untuk pengadaan pakan ternak (Maidala and Abdullahi, 2016). Pakan menyediakan sumber nutrien seperti protein, mineral, vitamin, karbohidarat dan lemak sebagai penyedia energi bagi ternak.

Jagung merupakan sumber energi utama dalam pakan broiler, penggunaannya mencapai 50-60\% (Yunusa et al., 2014; Edi, 2021) Kebutuhan jagung nasional lebih tinggi daripada produksi, karena itu maka dipenuhi dengan mengimpor dari negara lain. Lima puluh delapan persen penggunaan jagung nasional untuk bahan baku industri pakan ternak (Panikkai et al., 2017). Penggunaan bahan pakan sumber energi alternatif lain perlu dilakukan, untuk mengurangi ketergantungan akan jagung. Pemanfaatan sumber-sumber bahan pahan dari limbah pertanian dan hasil pertanian perlu dilakukan untuk menggantikan penggunaan jagung (Chrysostomus et al., 2020). Umbi Amorphophallus companulatus (AC) merupakan salah satu tumbuhan yang dapat dijadikan bahan pakan sumber energi.

Tanaman AC ini merupakan tanaman yang tumbuh secara liar di hutan dan belum dibudidayakan secara luas di Indonesia (Santosa et al., 2013). Umbi tanaman AC dapat dijadikan bahan pakan, dan biasa dijadikan pakan ternak babi dan produksi AC di NTT 4-5 $\mathrm{kg}$ umbi per rumpun (Koni et al., 2015). Tanaman AC telah dibudidayakan di India dengan produksi 50-80 ton/ha (Singh and Wadhwa, 2014). Di Malaysia, Filipina, Banglades, dan India. Umbi tanaman ini telah digunakan sebagai bahan pangan tradisional
(Paul et al.,2013; Santosa et al., 2013) dan sebagai bahan pakan (Paul et al., 2013).

Kandungan nutrien umbi AC yaitu protein kasar 7,33\%, gross energi 3570,60 kcal $/ \mathrm{kg}$ (Koni et al., 2015); kalium 327, $83 \mathrm{mg} / 100 \mathrm{~g}$, fosfor 166,91 mg/100 g, Kalsium 161,08 $\mathrm{mg} / 100 \mathrm{~g}$ dan Fe 3,43 mg/100 g (Kumar et al., 2017), dan kadar serat kasar $13,71 \%$ (Widiastuti et al., 2020). Berdasarkan kandungan nutrien dan ketersediaannya maka dilakukan penelitian yang bertujuan untuk mengkaji tingkat penggunaan umbi AC terhadap bobot potong, berat karkas dan lemak abdominal ayam broiler.

\section{Materi dan Metode}

Persiapan kandang

Satu bulan sebelum penelitian dilaksanakan terlebih dahulu dilakukan pembersihan kandang menggunakan air dan detergen, dilanjutkan dengan penyucihamaan kandang dan peralatan menggunakan desinfektan.

Persiapan umbi Amorphophallus companulats (AC)

Umbi AC diambil dari Desa Oebesi Kecamatan Amarasi Timur Kabupaten Kupang, Nusa Tenggara Timur. Umbi dibersihkan dengan air mengalir untuk mengeluarkan tanah pada kulit umbi. Umbi diiris $\pm 7 \mathrm{~cm}$ dengan ketebalan $\pm 3 \mathrm{~cm}$ dan kemudian dikeringkan dengan cara dijemur dibawah sinar matahari selama \pm 2 hari, setelah kering umbi digiling. Setelah digiling siap dicampurkan dengan bahan pakan lainnya. Pakan perlakuan dibedakan berdasarkan penggunaan $A C$. Pakan perlakuan disusun dengan kandungan protein kasar berkisar 21,02 hingga 21,39\% dan energi metabolisme 3027,17- 2044,77 kcal/kg (Tabel 1)

Percobaan biologis

Penelitian ini menggunakan ayam broiler jantan. Pakan yang diberikan dalam bentuk mash, pakan dan air minum diberikan ad libitum. Untuk pencegahan penyakit Newcastle 
Disease (ND) dilakukan vaksinasi menggunakan vaksin "medivac ND Hitchner B1" pada umur 4 hari dengan cara tetes mata. Pada hari ke-35 diambil secara acak dua ekor ayam per unit satuan percobaan untuk dipotong dan diukur berat karkas, lemak abdominal. Lemak abdominal merupakan lemak yang terdapat di sekeliling gizzard dan yang menempel antara otot abdominal dan usus buntu.

Tabel 1. Formulasi (\%) dan kandungan nutrien pakan perlakuan

\begin{tabular}{|c|c|c|c|c|c|}
\hline \multirow{2}{*}{ No } & \multirow{2}{*}{ Bahan Pakan } & \multicolumn{4}{|c|}{ Level umbi Amorphophallus companulatus (\%) } \\
\hline & & 0 & 5 & 10 & 15 \\
\hline 1 & Jagung & 53,00 & 50,50 & 48,00 & 45,50 \\
\hline 2 & Dedak Halus & 13,00 & 10,50 & 8,00 & 5,50 \\
\hline 3 & Tepung daging dan tulang & 7,35 & 7,35 & 7,35 & 7,35 \\
\hline 4 & Bungkil Kedelai & 25,00 & 25,00 & 25,00 & 25,00 \\
\hline 5 & Premix & 0,50 & 0,50 & 0,50 & 0,50 \\
\hline 6 & DL-Metionin & 0,30 & 0,30 & 0,30 & 0,30 \\
\hline 7 & L- Lysin $\mathrm{HCl}$ & 0,60 & 0,60 & 0,60 & 0,60 \\
\hline 8 & $\mathrm{NaCl}$ & 0,25 & 0,25 & 0,25 & 0,25 \\
\hline 9 & Amorphophallus companulatus & 0,00 & 5,00 & 10,00 & 10,00 \\
\hline 10 & Total & 100,00 & 100,00 & 100,00 & 100,00 \\
\hline \multicolumn{6}{|c|}{ Kandungan nutrien pakan perlakuan } \\
\hline 1 & Bahan Kering (\%) & 86,77 & 86,56 & 86,35 & 86,14 \\
\hline 2 & Protein kasar (\%) & 21,39 & 21,27 & 21,15 & 21,02 \\
\hline 3 & Energi Metabolisme (Kcal/kg) & 3027,17 & 3029,32 & 3031,47 & 3033,62 \\
\hline 4 & Serat Kasar $(\%)$ & 4,25 & 4,02 & 3,79 & 3,57 \\
\hline 5 & Lemak Kasar (\%) & 4,24 & 3,97 & 3,71 & 3,44 \\
\hline 6 & Calsium (\%) & 0,91 & 0,9 & 0,9 & 0,89 \\
\hline 7 & Fosfor (\%) & 0,48 & 0,48 & 0,49 & 0,49 \\
\hline 8 & $\operatorname{Lisin}(\%)$ & 1,02 & 1,01 & 1 & 1 \\
\hline 9 & Metionin (\%) & 0,53 & 0,53 & 0,52 & 0,52 \\
\hline
\end{tabular}

\section{Parameter penelitian}

Parameter penelitian yaitu bobot potong, berat karkas dan berat lemak abdominal. Bobot potong, diperoleh dengan menimbang ayam yang sebelumnya telah dipuasakan selama 6 jam, bobot potong dinyatakan dengan g/ekor. Berat karkas diperoleh dari hasil penimbangan setelah dipotong dan dikurangi berat kepala, leher, kaki dan viscera, berat karkas dinyatakan dengan g/ekor. Lemak abdominal diperoleh dari lemak didalam rongga perut termasuk disekitar organ pencernaan.

\section{Analisis data}

Penelitian ini menggunakan rancangan acak lengkap pola searah, dengan empat perlakuan dan empat ulangan, masing-masing ulangan berisi 7 ekor ayam. Keempat perlakuan yaitu P0 (Ransum kontrol tanpa AC);
P1(ransum yang mengandung 5\% AC); P2 (ransum yang mengandung 10\% AC); P3 (ransum yang mengandung 15\% AC). Data yang diperoleh dianalisis dengan menggunakan analisis ragam (ANOVA) dan dilanjutkan dengan Uji Jarak Berganda Duncan (Gomez dan Gomez, 2010)

\section{Hasil dan Pembahasan}

Bobot potong.

Bobot potong, diperoleh dengan menimbang ayam yang sebelumnya telah dipuasakan (Jumiati et al., 2017). Bobot potong, berat karkas dan bobot lemak abdominal ayam broiler yang diberi umbi AC disajikan pada Tabel 2.

Pemberian umbi AC berpengaruh sangat nyata $(\mathrm{P}<0,01)$ terhadap bobot potong ayam 
broiler. Semakin tinggi pemberian umbi AC maka semakin turun bobot potong ayam broiler. Penurunan bobot potong ini disebabkan karena rendahnya konsumsi pakan pada ayam perlakuan yang diberi umbi AC yaitu berkisar 1824,43 hingga 2083,61 g sedangkan pada perlakuan kontrol konsumsi sebesar 2637,14 g (Koni et al., 2017a). Bobot potong yang rendah pada ayam yang diberi AC disebabkan karena kandungan antinutrien seperti oksalat, tanin pada umbi tersebut. Koni et al. (2017b) menyatakan bahwa-umbi AC mengandung $318,51 \mathrm{mg} / \mathrm{kg}$ oksalat, $0,456 \%$ tanin, 35,88 ppm HCN dan 0,165 fitat. Rahman et al. (2017) menyatakan bahwa oksalat dapat menyebabkan turunnya pertumbuhan pada ternak karena penurunan konsumsi dan terganggunya pembentukan tulang karena oksalat dapat mengikat kalsium yang dibutuhkan dalam pembentukan tulang. Umbi Amorphophallus sp mengandung kristal kalsium oksalat (Novita dan Indriyani, 2013; Kumar et al., 2017)

Tabel 2. Rerata bobot potong, berat karkas dan bobot lemak abdominal ayam broiler yang diberi umbi $\mathrm{AC}$

\begin{tabular}{crrr}
\hline \multirow{2}{*}{ Perlakuan } & \multicolumn{3}{c}{ Parameter } \\
\cline { 2 - 4 } & Bobot potong (g/ekor) & Berat karkas (g/ekor) & Bobot lemak abdominal (g/ekor) \\
\hline P0 & $1500,00 \pm 43,08^{\mathrm{a}}$ & $1085,25 \pm 25,48^{\mathrm{a}}$ & $10,73 \pm 2,63^{\mathrm{a}}$ \\
P1 & $872,75 \pm 13,98^{\mathrm{b}}$ & $630,13 \pm 20,86^{\mathrm{b}}$ & $5,41 \pm 2,57^{\mathrm{b}}$ \\
P2 & $819,50 \pm 10,50^{\mathrm{c}}$ & $599,75 \pm 17,19^{\mathrm{c}}$ & $5,05 \pm 1,42^{\mathrm{b}}$ \\
P3 & $707,75 \pm 56,95^{\mathrm{d}}$ & $513,13 \pm 41,14^{\mathrm{d}}$ & $5,00 \pm 0,47^{\mathrm{b}}$ \\
\hline
\end{tabular}

Keterangan : P0 (Ransum kontrol tanpa AC); P1(ransum yang mengandung 5\% AC); P2 (ransum yang mengandung 10\% AC); P3 (ransum yang mengandung 15\% AC). Perlakuan sangat berpengaruh terhadap konsumsi pakan, bobot badan serta konversi pakan $(\mathrm{P}<0,01) .{ }^{\text {abcd }}$ superskrip yang berbeda pada kolom yang sama menunjukan berbeda nyata $(\mathrm{P}<0,05)$

Abdulrashid and Agwunobi (2009) menyatakan bahwa umbi Colocasia esculenta mengandung oksalat 45,30 $\pm 0,02 \mathrm{mg} / 100 \mathrm{~g}$, peningkatan pemberian umbi Colocasia esculenta 0, 25, 50 dan $100 \%$ menyebabkan penurunan bobot badan ayam broiler yaitu 2880, 2830, 2290, dan 1880 g. Robertson (2015) melaporkan bahwa bobot badan ayam White leghorn umur 6 minggu menurun dengan adanya peningkatan asam oksalat dalam pakan yaitu 495, 464, 460, $392 \mathrm{~g}$ pada masing pemberian $0,0,25,0,50,1 \%$ asam oksalat

Berat karkas

Hasil analisis statistik menunjukkan bahwa pemberian umbi $A C$ berpengaruh sangat nyata $(\mathrm{P}<0,01)$ terhadap berat karkas ayam broiler. Berat karkas ayam broiler dari perlakuan kontrol (P0) lebih tinggi $(\mathrm{P}<0,01)$ daripada perlakuan yang diberi umbi AC (P1-P3). Hal ini disebabkan rendahnya bobot badan pada kelompok ayam yang diberi umbi AC sehingga berat karkas yang diperoleh pun kecil. Wahju (2015) menyatakan bahwa tingginya berat karkas dipengaruhi oleh bobot akhir.

Antinutrien yang ada pada umbi Amorphophallus sp. menyebabkan rendahnya kecernaan nutrien sehingga mempengaruhi rendahnya karkas yang dihasilkan. Semakin tinggi penggunaan umbi AC maka semakin rendah berat karkas yang dihasilkan P3 nyata lebih rendah $(\mathrm{P}<0,05)$ dari pada $\mathrm{P} 2$ dan $\mathrm{P} 1$, dan $\mathrm{P} 2$ nyata lebih rendah $(\mathrm{P}<0,05)$ daripada $\mathrm{P} 1$. Hal ini karena semakin tinggi penggunaan umbi AC maka semakin tinggi akumulasi anti nutrien pada pakan tersebut. Pada umbi Amorphophallus sp, mengandung kalsium oksalat yang sebesar $2,1 \%$ dan dapat mengakibatkan kerusakan ginjal dan kematian (Krysanti dan Widjanarko, 2014). Abdulrashid and Agwunobi (2009) menyatakan bahwa berat karkas ayam broiler yang diberi pakan kontrol $1,90 \pm 0,29 \mathrm{~kg}$ sedangkan yang diberi $40 \%$ Colocasia esculenta $1,60 \pm 0,08 \mathrm{~kg}$, penurunan berat karkas ini karena kandungan oksalat Colocasia esculenta sebesar 45,30 $\pm 0,02$ $\mathrm{mg} / 100 \mathrm{~g}$.

Lemak abdominal

Hasil penelitian menunjukkan bahwa pemberian umbi AC berpengaruh sangat nyata $(\mathrm{P}<0,01)$ terhadap bobot lemak abdominal ayam broiler. Lemak abdominal ayam broiler yang diberi pakan kontrol (P0) lebih tinggi $(\mathrm{P}<0,01)$ daripada kelompok yang diberi umbi AC (P1-P3). Rendahnya lemak abdominal ayam yang diberi umbi AC karena energi yang terkonsumsi belum dapat memenuhi kebutuhan 
ternak sehingga deposit energi dalam bentuk lemak abdominal rendah. Selain itu umbi Amorphophallus sp memiliki kandungan karbohidrat dalam bentuk glukomanan yang sangat baik untuk pengurangan kandungan lemak tubuh. Harijati et al. (2011) menyatakan bahwa pemberian umbi Amorphophallus muelleri dapat mengurangi low-density lipoprotein cholesterol (LDL) pada tikus, LDL ini penting dalam proses pembentuk lemak tubuh. Widiastuti et al. (2020) menyatakan bahwa indeks glisemik yang rendah pada Amorphophallus sehingga karbohidrat yang dikonsumsi lambat disimpan dalam bentuk lemak; Amorphophallus mempunyai kadar pati (starch) yang bagus untuk penderita obesitas dan hiperlipidemia (Suriya et al., 2017).

\section{Kesimpulan}

Pemberian umbi AC dalam pakan broiler menurunkan bobot potong, berat karkas dan lemak abdominal ayam broiler. Umbi AC perlu diolah sebelum dijadikan bahan pakan untuk mengurangi kadar anti nutrien.

\section{Daftar Pustaka}

Abdulrashid M and Agwunobi L. 2009. "Taro cocoyam (Colocasia esculenta) meal as feed ingredient in poultry". Pakistan Journal of Nutrition, 8(5), 668-673.

Chrysostomus HY, Koni TNI dan Foenay TAY. 2020. "Pengaruh berbagai aditif terhadap kandungan serat kasar dan mineral silase kulit pisang kepok". Jurnal Ilmu Peternakan Dan Veteriner Tropis, 10(2), https://doi.org/10.46549/jipvet.v10i2.100

Edi DN. 2021. "Bahan pakan alternatif sumber energi untuk subtitusi jagung pada unggas (ulasan)". Jurnal Peternakan Indonesia, 23(1), 43-61. https://doi.org/10.25077/jpi.23.1.4361.2021

Gomez K dan Gomez AA. 2010. "Prosedur Statistik untuk Penelitian Pertanian" (2nd ed.). Penerbit universitas Indonesia (UIPress).Jakarta

Harijati N, Widyarti S, and Azrianingsih R. 2011. "Effect of dietary amorphophallus sp from East Java on LDL-C rats ( Rattus novergicus Wistar Strain ) ". Journal
Tropica Life. Science, 1(2), 50-54.

Jumiati S, Nuraini N, dan Aka R. 2017. "Bobot potong, karkas, giblet dan lemak abdominal ayam broiler yang temulawak (Curcumaxanthorrhiza,roxb) dalam pakan". Jurnal Ilmu Dan Teknologi Peternakan Tropis, 4(3), 11. https://doi.org/10.33772/jitro.v4i3.3634

Koni TNI, Paga A, Wea R, and Foenay TYA. 2015. "Nutritive value and metabolizable energy of Amorphophallus companulatus fermented by Rhizopus oligosporus as poultry feed". Pakistan Journal of Nutrition, 14(6), 322-324.

Koni TNI. Zuprizal. Rusman dan Hanim C. 2017.a. "Pemanfaatan umbi Amorphophallus companulatus terhadap pertumbuhan broiler". Seminar Nasional Peternakan Tropis Berkelanjutan 2, 3236.

Koni TNI, Rusman, Hanim C, and Zuprizal. 2017.b. "Nutritional composition and antinutrient content of elephant foot yam (Amorphophallus campanulatus)". Pakistan Journal of Nutrition, 16(12), 935-939.

https://doi.org/10.3923/pjn.2017.935-939

Krysanti A and Widjanarko SB. 2014. "Subacute Toxicity testing of glucomannan ( A . muelleri Blume) toward SGOT and sodium of Wistar Rats by in vivo". Jurnal Pangan Dan Agroindustri, 2(1), 1-7.

Kumar A, Patel AA, and Gupta VK. 2017. "Reduction in oxalate, acridity, phenolic content and antioxidant activity of Amorphophallus paeoniifolius var. Gajendra upon cooking". International Food Research Journal, 24(4), 16141620.

Maidala A, and Abdullahi IB. 2016. "Utilization of Millet ( Pennisetum Spp ) as an energy soure by broiler chickens : a review". International Journal of Agriculture and Earth Science, 2(7), 1824.

Novita MDA, dan Indriyani S. 2013. "Kerapatan dan bentuk kristal kalsium oksalat umbi porang (Amorphophallus muelleri Blume) pada fase pertengahan pertumbuhan hasil penanaman dengan perlakuan pupuk $\mathrm{P}$ dan $\mathrm{K}$ ”. Jurnal 
Biotropika, 1(2), 66-70.

Panikkai S, Nurmalina R, Mulatsih S, dan Purwati H. 2017. "Analisis ketersediaan jagung nasional menuju pencapaian swasembada dengan pendekatan modek dinamik". Informatika Pertanian, 26(1), 41.

Paul KK, Bari MA, Islam SMS. and Debnath SC. 2013. "In vitro shoot regeneration in elephant foot yam Amorphophallus companulatus blume". Plant Tissue Cult. and Biotech., 23(1), 121-126.

Pratiwi E. 2010. "Degradasi kalsium oksalat pada pembuatan chip porang (Amorphophallus onchophyllus)". Jurnal Teknologi Pangan Dan Hasil Pertanian, 7(1), 56-59.

Rahman MM, Rahman RM, Niimi M, Khadijah WEW, Akashi R and Abdullah R. 2017. "Effects of different levels of oxalic acid administration on feed intake and nutrient digestibility in goats". Sains Malaysiana, 46(4), 515-520. https://doi.org/10.17576/jsm-2017-460401

Robertson MC. 2015. "Bioavailability of Dietary Oxalate". The University of Alabama at Birmingham.

Santosa E, Halimah S, Susila AD, Lontoh AP, Mine Y and Sugiyama N. 2013. KNO 3 Application Affect Growth and Production of Amorphophallus muelleri Blume". Jurnal Agronomi Indonesia,
41(3), 228-234.

Singh A and Wadhwa N. 2014. "A review on multiple potential of aroid: Amorphophallus paeoniifolius". International Journal of Pharmaceutical Sciences Review and Research, 24(1), 5560.

Suriya M, Rethina C, Bashir M, Reddy CK, Harsha N and Haripriya S. 2017. "Impact of irradiation on physicochemical properties of freeze dried Amorphophallus paeoniifolius flour". Food Chemistry, 234, 276-284.

https://doi.org/10.1016/j.foodchem.2017. 05.001

Wahju J. 2015. "Ilmu Nutrisi Unggas" (6th ed.). Gadjah Mada University Press.

Widiastuti ES, Rosyidi D, Radiati LE and Purwadi P. 2020. "The effect of elephant foot yam (Amorphophallus campanulatus) flour and soybean oil addition on the physicochemical and sensory properties of beef sausage". Jurnal Ilmu Dan Teknologi Hasil Ternak, 15(2), 119-130. https://doi.org/10.21776/ub.jitek.2020.01 5.02 .7

Yunusa Y, Doma UD, Zahraddeen D, Umar A and Abubakar SB. 2014. "carcass and gut characteristics of broiler chicken fed different energy sources". International Journal of Poultry Science, 13(9), 525529. 